\title{
Dawne portrety fotograficzne kontra selfie? Fotografia jako temat i przedmiot lekcji języka polskiego
}

\author{
Past Photographic Portraits Versus Selfies? -
}

Photography as the Topic and Subject of the Lesson in Polish Language

Summary: What is the subject of the work is the interpretation of the fifth essay from the book Camera Lucida by Roland Barthes juxtaposed with the phenomenon of taking pictures of yourself and making them public on the Internet. The author makes a description of the phenomenon called 'selfie culture', makes it subject to analysis, pointing to its advantages and disadvantages. In addition, while describing classes dealing with photography, she shows how to use selfies in didactics.

Key words: selfie, photography, portrait, social networks

\section{Stare kontra nowe?}

Pierwszy fotograficzny autoportret w historii fotografii został zrobiony przez Roberta Corneliusa w 1839 roku i traktuje się go jak dokument artystycznych możliwości dawnych aparatów fotograficznych. Gdy Kodak w 1900 roku wypuścił na rynek pierwszy przenośny aparat fotograficzny, robienie sobie zdjęć stało się możliwe'. Jednakże początek mody na robienie zdjęć sobie,

${ }^{1}$ B. Brauchitsch: Mała historia fotografii. Tłum. J. Koźbiał, B. Tarnas. Warszawa 2004, s. 107. 
jak i na używanie słowa: „selfie"”, można datować dopiero na rok 2002, co wiąże się bezpośrednio z rozwojem mediów społecznościowych. Współcześnie istnieje bardzo wiele odmian tego typu fotografii, jak i technik ich wykonywania. Popularność zjawiska może sprawić, że odpowiednio wykorzystane selfie stanie się przydatnym narzędziem dydaktycznym. Nieprzypadkowo tytuł artykułu został opatrzony znakiem zapytania. Analiza zjawisk kulturowych nie powinna polegać na wartościowaniu nowego starym - w tym przypadku modnego selfie dawną, opatrzoną etykietką sztuki, fotografią - ale na rzetelnym i obiektywnym skomentowaniu nowego zjawiska. Tytuł stawiający nowoczesne cyfrowe selfie w opozycji do analogowego zdjęcia-portretu został zastosowany w celu wzbudzenia zainteresowania uczniów i pobudzenia ich do głębszej refleksji na temat kultury, w której funkcjonują ${ }^{3}$. Trzeba wyraźnie zaznaczyć, że „kultura selfie ${ }^{4 ”}$ jest faktem i nie możemy, jako badacze i uczestnicy tej kultury, pozostawić jej bez głębszej refleksji, nawet jeśli oceniamy ją krytycznie.

Dodatkowo warto pamiętać, że wśród tekstów kultury, które pojawiają się na lekcjach języka polskiego, istnieje możliwość „,czytania” fotografii — bezpośrednio, jak obrazu, lub pośrednio, jako motywu literackiego, pojawiającego się w tekstach różnych autorów ${ }^{5}$. Warsztaty interpretacyjne lub po prostu lekcje o fotografii mogą poprzedzać interpretację utworów literackich inspirowanych fotografią twórców wymienionych w podstawie programowej, np. wiersza Stanisława Barańczaka Zdjęcie.

Tekstową bazę rozważań stanowią fragmenty książki Rolanda Barthes'a Światło obrazu. Eseje o fotografii ${ }^{6}$, które pozwolą: po pierwsze — przećwiczyć z uczniami pracę z fragmentem tekstu; po drugie - powtórzyć cechy eseju jako formy literackiej; po trzecie - pobudzić do dyskusji o stanie współczesnej kultury fotografii. Obecnie rynek książki zalany jest literaturą techniczną, eseistyczną czy psychologiczną, traktującą o fenomenie fotografii. Książka Barthes'a na ich tle wydawać się może zdezaktualizowana i mało ekspercka, jednakże wnioski płynące z jej lektury są szokujące i pobudzają do zrewidowania myślenia na temat fotografii w ogóle. Ponadto warto zauważyć, że wprowadzając fragmenty tej książki do lekcji języka polskiego, zapoznajemy uczniów

${ }^{2} \mathrm{~W}$ języku polskim przez krótki czas funkcjonowało pojęcie: ,zdjęcie z ręki/rąsi”.

${ }^{3}$ Pominięcie w rozważaniach drukowanej fotografii cyfrowej i selfie prywatnego, tzn. nieupublicznionego, jest celowe.

${ }^{4}$ A. Scholz: Selfie ergo sum?. Tłum. P. Kasprzyk. http://www.cafebabel.pl/lifestyle/arty $\mathrm{kul} / \mathrm{selfie}$-ergo-sum.html [data dostępu: 29.09.2017].

${ }^{5}$ Mowa tu o utworach inspirowanych fotografią lub tekstach, w których zdjęcie stanowi element składowy, np. W. Nowickiego: Dno oka. Eseje o fotografii lub W. Szymborskiej: Album, Fotografia z 11 września.

${ }^{6}$ R. Barthes: Światto obrazu. Eseje o fotografii. Tłum. J. Trznadel. Warszawa 2008. 
z dość trudną twórczością teoretyka literatury, do której, na etapie kształcenia szkoły średniej, raczej nie dotarliby bez odpowiedniej zachęty?

\section{Definicja selfie}

Słownik Merriam-Webster definiuje selfie jako:

zdjęcie siebie samego zrobione przez siebie za pomocą aparatu cyfrowego, zwłaszcza w celu umieszczenia na portalu społecznościowym ${ }^{8}$.

W języku angielskim „selfie” powstało jako rzeczownik od zaimka self, czyli 'się'. Wszystkie polskie odpowiedniki tego sformułowania zdają się nieadekwatne. Pierwszy z nich — autoportret — zaczerpnięty z języka sztuki, rozumiany jest jako portret artysty wykonany przez niego samego. Użycie tego pojęcia narzuca rejestr zbyt wysoki w konfrontacji z trywialną praktyką , robienia sobie fotek i udostępniania ich w sieci”. Ponadto warto zauważyć, że tworzenie autoportretu (z jego literackim odpowiednikiem — autobiografią) wiąże się z poznawaniem swojego ,ja" głębokiego. Gdy pojawia się czynnik zwany publicznością, obraz ,ja” zawsze ulega modyfikacji, ugładzeniu, rozmyciu. W czynności robienia sobie zdjęć, w celu udostępnienia ich w Internecie, trudno dopatrywać się psychologicznego procesu poznawania własnego ego. Motywacją takiego zachowania będzie raczej próba podniesienia własnej samooceny przez publikacje zdjęć w oczekiwaniu na „polubienie” czy pochlebne komentarze ${ }^{10}$.

Drugi odpowiednik słowa selfie — ,samojebka” — pochodzi z rejestru wulgarnego i ma wyraźnie pejoratywne zabarwienie emocjonalne. Rzeczownik ten stworzony został przez użytkowników Internetu, którzy niekoniecznie z entu-

${ }^{7}$ Opisywane warsztaty odbyły się podczas Dni Humanistyki 7-8 grudnia 2017 roku w II LO im. Gustawa Morcinka w Rudzie Śląskiej. Warto wspomnieć, że większość uczniów po zajęciach zgłosiła chęć sięgnięcia po całość książki Światto obrazu. Eseje o fotografii, argumentując stwierdzeniem: „widać, że dobrze się to czyta”. Praca z fragmentem okazała się więc owocna. Jednak trzeba zaznaczyć, że warsztaty te nie miały ograniczeń czasowych.

${ }^{8}$ A. Scholz: Selfie ergo..., http://www.cafebabel.pl/lifestyle/artykul/selfie-ergo-sum.html [data dostępu: 29.09.2017].

${ }^{9}$ R. Lubas-Bartoszyńska: Nowsze problemy teoretyczne pisania o sobie. Przykłady wypowiedzi autobiograficznych pisarzy ostatnich dziesięcioleci. „Przestrzenie Teorii” 2006, nr 6, s. 63.

${ }^{10}$ Warto podkreślić, że w netykiecie obowiązuje zasada tylko pochlebnego komentowania czyichś zdjęć, każdą krytykę, chociażby konstruktywną, uznaje się za nietakt, hejt. Inaczej ma się sprawa wymiany opinii, wtedy każda konstruktywna krytyka jest pożądana. Ta agresywna, bezpodstawna nosi nazwę hate speech. 
zjazmem przyjęli nową modę. Źródłosłów prawdopodobnie wywiedziono ze skojarzania $\mathrm{z}$ autoerotyzmem ${ }^{11}$ i ma on oddawać krytykę samouwielbienia realizowaną poprzez robienie zdjęć sobie. Jednakże poprzez powielenie tej nazwy w komentarzach czy za pomocą memów, wyraz „samojebka” szybko trafił do sloganu młodzieżowego, gdzie stracił swój negatywny wydźwięk i stał się, powszechnym, ale jednak wulgarnym synonimem selfie.

Z braku polskiego odpowiednika słowa „selfie” zmuszona jestem do używania tego pojęcia w języku angielskim.

\section{Fotografia analogowa kontra cyfrowa}

„Czytanie” fotografii, czyli jej interpretacja, może być sztuką na równi z samym fotografowaniem. Potwierdzenie tej tezy stanowią eseje Barthes'a, Susan Sontag $^{12}$, Johna Bergera ${ }^{13}$, a współcześnie twórczość Wojciecha Nowickiego ${ }^{14}$ czy Jacka Dehnela ${ }^{15}$. Zwracają oni szczególnie uwagę na magię starych zdjęć i choć nie deprecjonują fotografii cyfrowej, zdają się jednak skłaniać ku opinii, że powszechność aparatu niszczy istotę fotografowania. Autorzy ci traktują fotografię jak zjawisko kulturowe, może nawet sztukę, dokonując subiektywnej selekcji, na zasadzie — podoba mi się, nie podoba mi się — ponieważ nie każdemu i nie każde zdjęcie pozwoli się zinterpretować. Młodzi ludzi przyznają, że równie często jak fotografują siebie, tak i przeglądają czyjeś lub swoje zdjęcia na portalach społecznościowych, lecz bez głębszego wpatrywania się. Dawniej fotografie oglądało się rzadziej, z odpowiednim ceremoniałem w zakurzonych albumach rodzinnych. Dziś, będąc aktywnymi użytkownikami platform społecznościowych, obcujemy z obrazami fotograficznymi praktycznie cały czas, ale bez zastanawiania się czy refleksji, czasem tylko siląc się na czysto kurtuazyjny komentarz.

Chcąc wprowadzić uczniów w magię dawnych zdjęć i w nastrój skłaniający do ich interpretacji, rozpoczynam warsztaty od wyświetlenia czarno-białej fotografii analogowej i rozmowy na jej temat. Szybko okazuje się, że próba interpretacji zdjęcia opiera się głównie na zadawaniu pytań, na które nie sposób znaleźć odpowiedzi. Jednak już sama zdolność „zapytania” udowadnia, że obraz pobu-

${ }^{11}$ Słowo ,jebać” pochodzi od starosłowiańskiego *jebat, *jebati, a to z praindoeuropejskiego *yebh- (spółkować), choć obecnie ma bardzo wiele znaczeń niekonieczne spójnych z pierwotnym.

12 S. Sontag: O fotografii. Tłum. S. Magala. Warszawa 1986.

13 J. B erger: O patrzeniu. Tłum. S. Sikora. Warszawa 1999, s. 71-89.

${ }^{14}$ W. Nowicki: Dno oka. Eseje o fotografii. Wołowiec 2010.

15 J. Dehnel: Fotoplastikon. Warszawa 2009. 
dza do myślenia. Uczniowie dostrzegają, że mogą jedynie własnym językiem opowiedzieć hipotetyczną historię zatrzymaną w kadrze, ale będzie miała ona więcej wspólnego z ich wyobraźnią niż z rzeczywistością, ponieważ ich pamięć nie posiada danych na temat sytuacji uchwyconej na zdjęciu.

$\mathrm{Z}$ tego właśnie powodu poprosiłam uczniów, by zrobili sobie zdjęcie i coś o nim powiedzieli. Niemal wszyscy mówili o SOBIE. Eksperyment z wykonaniem selfie pokazał, jak bardzo czują się związani z własnym odbiciem. $\mathrm{Na}$ temat prostego zdjęcia zrobionego sobie byli w stanie powiedzieć o wiele więcej niż na temat poruszającej, ale dawnej fotografii, ponieważ czuli się częścią tego konkretnego selfie. By znaleźć odpowiedź na pytanie: skąd bierze się tak mocne przywiązanie do własnego wizerunku, trzeba zagłębić się w poszukiwania istoty fotografii samej w sobie. W tym celu uczniowie zestawili dawny portret z selfie, wynotowując różnice i podobieństwa między nimi. Stare portrety wykonywane były aparatem analogowym obsługiwanym przez fotografa, który miał nikłą możliwość ingerencji w zdjęcie (fotoedycji, fotomontażu) już po jego wykonaniu. Natomiast selfie robi się samodzielnie smartfonem z wbudowanym aparatem cyfrowym, wykorzystując przy tym przeróżne techniczne sztuczki czy filtry, które zmieniają obraz w celu upiększenia lub deformacji. Fotograf, utrwalając czyjąś twarz, stara się wydobyć z niej ukryte piękno, uwiecznić charakter, nadać obrazowi znaczenie. A selfie... tu zdania mogą być bardzo podzielone. Od skrajnych stwierdzeń, że selfie ukazuje tylko pustkę, poprzez zdanie, że ten typ fotografii nie ujawnia, a wręcz zakrywa prawdziwy charakter, ujednolica, wpisuje w ramy pewnego modnego zachowania społecznego, po opinię, że autoportret fotograficzny oddaje wyjątkowość fotografującej się osoby i jest wyrazem chęci dzielenia się z innymi własnym życiem.

By nie opierać dyskusji tylko na własnych doświadczeniach, uczniowie czytają fragmenty piątego eseju wyjętego z książki Światto obrazu. Eseje o fotografii Barthes'a ${ }^{16}$. Tekst mówi wprawdzie o starych, analogowych zdjęciach, lecz jego autor w sposób wysoce metaforyczny snuje niemal filozoficzno-egzystencjalne rozważania na temat istoty całej fotografii jako zjawiska kulturowego, w co wpisuje się poniekąd również selfie. Jako podstawę do rozmowy stawiam pytania: jak zmienia się myślenie na temat fotografii, gdy mamy do czynienia ze zmianą narzędzia $\mathrm{z}$ aparatu analogowego na smartfona? Czy ze zmianą narzędzia rozważania Barthes’a się dezaktualizują, czy wręcz odwrotnie - nabierają nowych znaczeń?

${ }^{16} \mathrm{~W}$ trakcie warsztatów wykorzystano tylko fragmenty piątego eseju Rolanda Barthes'a z książki Światło obrazu. Eseje o fotografii. Jednakże w samym artykule odwołuję się również do innych źródeł. 


\section{Pozowanie}

Niezależnie czy mowa o selfie, czy o analogu, wykonanie każdego z nich poprzedza pozowanie, którego celem jest przede wszystkim „wyjście” na zdjęciu jak najkorzystniej. Barthes dopatruje się w tej czynności dużo głębszego problemu. Pisze:

A przecież, gdy tylko czuję się oglądany przez obiektyw, wszystko ulega zmianie: przybieram pozę, stwarzam sobie natychmiast inne ciało, z góry przekształcam się w obraz. To przekształcenie jest aktywne: czuję, że Fotografia stwarza moje ciało lub powoduje jego martwicę, według własnej zachcianki. [...] Moje istnienie zależy od fotografa tylko metaforycznie. Ale choć ta zależność jest tylko wyobrażona, przeżywam ją niespokojny i niepewny przyszłego podobieństwa: narodzi się obraz — obraz mnie. Nie wiem, jak działać od wewnątrz na swoją skórę. [...] Tak więc chciałbym, aby mój obraz, przerzucany między tysiącem zmieniających się zdjęć, zależnie od okoliczności i wieku, zgadzał się zawsze z moim ,ja” (głębokim, oczywiście). Trzeba jednak powiedzieć, że zachodzi coś przeciwnego: moje ,ja" nigdy się nie zgadza z moim obrazem ${ }^{17}$.

Fotografia przekształca osobę $\mathrm{w}$ czwórwymiarze ${ }^{18} \mathrm{w}$ płaski dwuwymiarowy przedmiot (obraz). Wiedza o tym, że jesteśmy fotografowani sprawia, że zaczynamy udawać, choć chcemy oddać własną naturę. Staramy się być sobą, a paradoksalnie przybieramy pozę. Dawniej proces pozowania-fotografowania trwał dłużej i wiązał się z zastyganiem, utrzymaniem miny. Czynności te wywoływały poczucie sztuczności, zniecierpliwienie, a nawet odrętwienie. Współcześnie czas samego pozowania i wykonywania fotografii skraca się do mniej niż sekundy, a efekty możemy obserwować od razu. Autor eseju twierdzi, że SAM przekształca się w obraz, choć rzetelniej byłoby powiedzieć, że czyni to fotograf za pośrednictwem aparatu fotograficznego. Pomijając sytuację, w której jesteśmy fotografowani bez naszej wiedzy, pozowanie zdaje się mniej lub bardziej świadomym pozoranctwem. Barthes pisze o aktywnym przekształcaniu się, ponieważ chce zostać uwieczniony. Ma to związek z pierwotnym pragnieniem życia wiecznego czy zostawienia cząstki siebie na ziemi po śmierci. Takie złudne poczucie nieśmiertelności wynika $\mathrm{z}$ wiary w powtarzany jak slogan mit fotografii. Ludzkość uwierzyła, że skrawek papieru ma zdolność zatrzymania chwili z całym jej znaczeniem i emocjami przeżywanymi w momencie wykonywania zdjęcia. W rzeczywistości jednak nietrwałość materiału sprawia, że dokumenty

\footnotetext{
${ }^{17}$ R. Barthes: Światto obrazu..., s. 25.

18 Przestrzeń trójwymiarowa umieszczona w płynącym czasie astralnym.
} 
historii blakną i z czasem znikają. Obraz, który miał być świadkiem historii, jest tylko kopią czegoś, o czym już nie pamiętamy ${ }^{19}$.

Dawniej społeczeństwa dbały o to, aby wspomnienie, substytut życia, było nieśmiertelne; a przynajmniej aby sama rzecz, wyrażająca śmierć, była nieśmiertelna - to był Pomnik. Czyniąc jednak ze śmiertelnej Fotografii generalnego i jakby naturalnego świadka „tego, co było”, nowoczesne społeczeństwo wyrzekło się pomnika ${ }^{20}$.

Pozostaje pytanie, czy zapis cyfrowy jest trwalszy? Potocznie mówi się, że „W sieci nic nie ginie”, „Internet nie zapomina” itd. ${ }^{21}$ Czy to oznacza, że współcześnie ludzkość przekroczyła granice nietrwałości materiału i nasze fotopomniki będą trwać wiecznie? Pomimo przekonywań programistów, szczerze wątpię w niezniszczalność danych komputerowych, ponieważ celem ich przechowywania nie jest zachowanie pamięci o każdym człowieku, lecz gromadzenie dokumentacji, a to istotna różnica. Konto na portalu społecznościowym, za pomocą wszystkich trafiających tam zdjęć, postów i komentarzy, pozwala tworzyć wirtualne alter ego właściciela danego profilu. Zdarza się, że prezentuje się ono lepiej niż rzeczywiste ,ja”, ponieważ do Internetu trafiają tylko wybrane zdjęcia, często poprawione i zmodyfikowane tak, by tworzyć spójny i ugrzeczniony wizerunek bez wad. Odnosząc problem pomnika do selfie, trudno za cel robienia samemu sobie zdjęć uznać pragnienie wiecznego istnienia. Uczniowie pytani o powody wykonywania tej czynności w większości odpowiadali, że selfie szybko wchodzi w nawyk i staje się działaniem naturalnym, jak jedzenie lub spoglądanie w lustro. Jednak zgodnie wszyscy przyznali, że przyczyną pierwszego selfie w ich życiu była ciekawość i chęć sprawdzenia możliwości swojego smartfona, a nie „uwiecznienie” siebie.

\section{„Ja" rzeczywiste, ,ja” odbite, ,ja” wirtualne}

Chociaż dawne i współczesne motywacje portretowania siebie rozeszły się w wielu różnych kierunkach, ich wspólny mianownik stanowi, w mniejszym lub

19 Powołuję się tu na sławną wypowiedź Marcela Prousta: ,zdjęcia nie są prostym narzędziem pamięci, lecz jej fundamentem, a bywa, że zastępują pamięć”. Zob. J. Berger: O patrzeniu..., s. 89.

${ }^{20}$ R. Barthes: Światto obrazu..., s. 166.

${ }^{21}$ Sieć WWW polega głównie na przechowywaniu bardzo dużej ilości danych w wielu kopiach zapasowych na różnych niezależnych serwerach. Zdjęcie, które trafia do Internetu, powielane jest w nieskończoność za pomocą specjalnych algorytmów. W teorii więc zostaje tam na zawsze. 
większym stopniu, próżność. Barthes wspomina o „lekkiej niechęci, którą odczuwamy, oglądając »siebie« na papierze ${ }^{22}$ ", ponieważ uwidacznia ona zawsze jakiś brak „czegoś” w nas, pewne niedopasowanie. Wydaje się nam, że w rzeczywistości jesteśmy ładniejsi. Jako usprawiedliwienie powstało nawet słowo „niefotogeniczność”, oznaczające nieładne „wychodzenie” na zdjęciach, w odmianie do domniemanego stanu rzeczywistego. Właściwie ten niesmak przy oglądaniu własnego wizerunku można by przypisać upływowi czasu i zmianom, jakie w nas nastąpiły od momentu zrobienia zdjęcia do jego wywołania/ oglądania, a jednak współcześnie, chociaż możemy obserwować fotografię praktycznie w tej samej sekundzie, w której ją zrobiliśmy, nadal odczuwamy tę samą niechęć. Berger, malarz i poeta, twierdzi, że odczucie niezdefiniowanego braku przy oglądaniu papierowej kopii własnego wizerunku bierze się stąd, że fotografia nie ma własnego języka, za pomocą którego mogłaby opowiedzieć, co pokazuje. Zauważa:

Fotografia, odmiennie niż pamięć, nie utrwala [...] znaczenia. Oferuje obrazy — z ich wiarogodnością i uwagą, którą zazwyczaj im użyczamy lecz obrazy odarte ze znaczenia. Znaczenie jest rezultatem rozumienia działania. „A działanie zachodzi w czasie i w czasie musi być wyjaśnione. Tylko narracja może nam pomóc w zrozumieniu czegokolwiek". Same fotografie nie opowiadają. Utrwalają tylko chwilowe obrazy ${ }^{23}$.

Barthes główną trudność w pisaniu i mówieniu o fotografii upatruje w niemożliwości uchwycenia tego, za pomocą jakich środków fotografia znaczy (signifiant), ponieważ ma ona w sobie zawsze coś z tautologii. Przedmiot uchwycony na zdjęciu zostaje zawsze tym samym przedmiotem „,pozującym” do zdjęcia ${ }^{24}$. Zdaniem Barthes'a

Fotografia zawsze zabiera ze sobą swoje odniesienie: ona i ono, dotknięte tym samym miłosnym lub żałobnym znieruchomieniem, pośród dziejącego się świata ${ }^{25}$.

Berger natomiast stawia tezę, że znaczenie fotografii uratować może tylko specyficzny rodzaj kontekstu — opowieść:

[...] kontekst lokuje ponownie fotografię w czasie — nie w jej oryginalnym czasie, bo to niemożliwe, lecz w czasie narracji. Czas narracji staje się

${ }^{22}$ R. Barthes: Światto obrazu..., s. 27.

${ }^{23}$ J. Berger: O patrzeniu..., s. 75.

${ }^{24} \mathrm{~W}$ przemyśle fotograficznym przedmiot, który będzie fotografowany, nazwany jest produktem, ponieważ robi się to głównie w celach marketingowych.

${ }_{25}$ R. Barthes: Światto obrazu..., s. 15. 
czasem historycznym, kiedy jest uznawany przez pamięć społeczną i działanie społeczne ${ }^{26}$.

Być może dlatego twórcy portali społecznościowych tworzyli opcje „opis zdjęcia” i „komentuj”, lecz — wbrew pragnieniu zachowania wspomnień strony te pełne są nic nieznaczących zdjęć podpisanych infantylnymi cytatami z popularnych piosenek lub myślami niszowych poetów czy celebrytów ${ }^{27}$.

Badając problem odczuwania niechęci przy oglądaniu siebie na zdjęciu, Barthes odwołuje się do mitu sobowtóra:

Widzieć siebie samego (inaczej niż w lustrze): to całkiem świeży nabytek w skali Historii, gdyż malowany czy rysowany portret, miniatura choćby był najpodobniejszy, nie jest zdjęciem fotograficznym. [...] Ciekawe, że nie pomyślano o niepokoju (cywilizacyjnym), który pojawia się wraz $\mathrm{z}$ tym nowym czynnikiem. Fotografia to pojawienie się mnie samego jako kogoś innego. Co ciekawsze: to przed powstaniem Fotografii ludzie mówili najwięcej o wizji sobowtóra. Stan, w którym chory widzi przed sobą swój obraz, kojarzy się ze stanem halucynacji; dzisiaj jednak jakby spychamy w nieświadomość głębokie obłąkanie Fotografii: przypomina ona o swoim dziedzictwie mistycznym tylko poprzez tę lekką niechęć, którą odczuwam, oglądając „siebie” na papierze ${ }^{28}$.

W odniesieniu do zwyczajnej papierowej fotografii mowa o „pojawieniu się mnie jako kogoś obcego" wydaje się nieco przedramatyzowana. Mój obraz zrodził się z mojego chwilowego ,ja" i wprawdzie jest pozbawionym znaczenia odbiciem, lecz ciągle przedstawia mnie, a dawne ,ja” zatrzymane w kadrze stanowi część składową teraźniejszego ego. Sprowadzenie oglądania własnej fotografii do spotkania z ,innym” wydaje się adekwatniejsze w przypadku przeglądania profili na portalach społecznościowych. Współcześnie, wrzucając swoje zdjęcia na konta w mediach społecznościowych, niejako zgodziliśmy się na „obecność” naszego sobowtóra (,ja” wirtualnego), nie odczuwamy przy tym lęku. Dawniej widzenie swojego sobowtóra zwiastowało bliską śmierć. Chory w malignie, widzący swe oblicze, myślał, że umarł i ogląda swoje ciało z zaświatów. Pozostaje więc pytanie, czy podwojenie ,ja" o internetowe alter ego nie świadczy o rychłej śmierci ,ja” rzeczywistego? Na ile ,ja” wirtualne jest spójne z,,ja” rzeczywistym?

${ }^{26}$ J. Berger: O patrzeniu..., s. 89.

${ }^{27}$ Lecz byłoby nierzetelnością niewspomnienie o współczesnych fotografiach, w tym selfie, które zasadę narracyjnego kontekstu realizują. Mowa tu o wszystkich selfie, które mają świadczyć nie tylko o tym, że uchwycone zdarzenie miało miejsce i jawi się jako ważne, ale że moje ,ja" zatrzymane w kadrze stało się jego częścią, np. sławne selfie z papieżem Franciszkiem, selfie po zdobyciu Mont Everestu, selfie z gali rozdania Oskarów itp.

${ }^{28}$ R. Barthes: Światto obrazu..., s. 27. 
W przypadku profili na portalach społecznościowych kontekst: opowieść dodana do zdjęcia, jawi się jako dość bogaty w informacje wskutek opatrywania zdjęć datą, opisem i komentarzami. Praktyka ta uchodzi za słuszną ze względu na łatwiejszą dokumentację życia i pielęgnację wspomnień. Czasami, przeglądając czyjś profil, możemy odnieść wrażenie, że bez społecznej interakcji udało się nam poznać rzeczywistą osobę. Niestety, przez folgowanie próżności zdarza się, że właściciel profilu selekcjonuje fakty i „upiększa” zdjęcia. Ten zabieg bywa tak dalece posunięty, że profil ma niewiele wspólnego z rzeczywistą postacią. W takiej sytuacji oglądanie własnego profilu przypomina spotkanie „,ja prawdziwego" $\mathrm{z}$,ja wyobrażonym”, ale czy obcym, innym? Odpowiedź na to pytanie należy zostawić psychologom.

Przyrównanie rozważań Barthes'a o fenomenie fotografii do mody na selfie (być może chwilowej w wymiarze wszechświata) początkowo może wydawać się spłyceniem jego myśli. Esej Barthes’a przedstawia analizę fenomenu fotografii na poziomie mitycznym, lecz zderzenie wniosków płynących z lektury ze zjawiskiem istnienia wirtualnych profili ujawnia, że młodzi ludzie mają problem z określeniem się. Powielanie swego, ,ja" paradoksalnie jest wyrazem poszukiwania spójności. Interpretacja fragmentów Światta obrazu... pomaga dostrzec wszelkie konsekwencje tej mody na selfie i każe albo całkiem zrewidować swoje myślenie na jej temat, albo przynajmniej zmusza do chwilowej refleksji. Fotografia przez próby wiązania przeszłości (,ja” wczoraj) z teraźniejszością (,ja” dziś) i przyszłością (,,ja” wyobrażony) ingeruje w delikatne kwestie psychologii i tożsamości. Każde zdjęcie uwieczniające osobę, nieważne czy portret zrobiony ręką fotografa czy selfie, w jakiś sposób fragmentuje, rozczłonkowuje spójną, budowaną każdego dnia, tożsamość. Stąd oczywiste pragnienie, by zdjęcie niosło tylko jedno znaczenie, oczywiście to nadane przez nas. Barthes przestrzega jednak, że

przed obiektywem jestem jednocześnie: tym, za kogo się uważam, tym, za kogo chciałbym, aby mnie brano, tym, za kogo ma mnie fotograf, i tym, którym on posługuje się, aby ujawnić swoją sztukę. Dziwna to czynność: bezustannie siebie imituję i właśnie dlatego za każdym razem, gdy chcę, aby mnie fotografowano, nieuchronnie przejmuje mnie uczucie nieautentyczności, czasem wprost oszustwa ${ }^{29}$.

Nie istnieje jeden i niezmienny kontekst portretu fotograficznego. Nawet w sytuacji, gdy fotograf i pozujący to ta sama osoba, a czas pozowania i oczekiwania na zdjęcie jest możliwie najkrótszy. Ilu oglądających, tyle narracji ${ }^{30}$.

${ }^{29}$ Ibidem, s. 28-29.

${ }^{30}$ Aby uzmysłowić uczniom Technikum $\mathrm{nr} 4 \mathrm{w}$ Bytomiu tę zależność, podczas warsztatów interpretacyjnych dla klas fotograficznych, poprosiłam uczniów, przyszłych fotografów, aby wybrali ze zdjęć swojego autorstwa jedno zdjęcie z przesłaniem. Następnie wysyłali mi je z opisem tego, 
Jakiekolwiek starania jeszcze w większym stopniu potęgują wrażenie imitacji „ja”. Praktyka, o której wspomina Barthes, traktowania fotografii jak dokumentu przekazującego bezwzględną prawdę, została dziś już prawie zarzucona. Przeglądając profile na Instagramie, odnosimy nierzadko wrażenie, że w tej wirtualnej ,zabawie” nie chodzi o prawdę, a o iluzję, dzięki której możemy być lepszą wersją siebie. Prawda o samym sobie wydaje się nudną, oklepaną opowieścią. Trzeba pamiętać jednak o tym, że kontekst nadaje oglądający, zlepiając swoją opowieść z informacji dostępnych mu w momencie oglądania (pamięć, data pod zdjęciem, krótka adnotacja, czasem skojarzenie, symbol lub po prostu urzeczenie daną sceną, twarzą, unieruchomionym gestem), dlatego selfie może nie nieść znaczenia $\mathrm{w}$ ogóle lub odwrotnie - mieć go w sobie bardzo wiele. Zwykłe selfie umieszczone w złym kontekście może kogoś z góry deprecjonować i nadać konkretną, społeczną etykietkę ${ }^{31}$. W tym miejscu uczniowie poproszeni zostali o wykonanie selfie z przesłaniem, a następnie udostępnienie go znajomym do zinterpretowania. Ten eksperyment pokazał, że odbiór fotografii jawi się jako czynność bardzo indywidualna i subiektywna, dlatego czytający moje zdjęcie/selfie/profil, nadając mu wyobrażony kontekst, może zrobić ze mną, co tylko zechce. Fotografia niejako pozbawia prywatności, a według Barthes'a nawet tożsamości:

Fotografia stanowi tę bardzo subtelną chwilę, gdy — prawdę mówiąc nie jestem ani podmiotem, ani przedmiotem, ale raczej podmiotem, który czuje, że staje się przedmiotem. Przeżywam wtedy mikrodoświadczenie śmierci: naprawdę staję się zjawą. [...] widzę, że stałem się Cały-Obrazem, to znaczy ucieleśnioną Śmiercią. Inni-Inny — pozbawiają mnie siebie samego, czynią ze mnie, z okrucieństwem, przedmiot, jestem na ich łasce, do ich rozporządzenia ${ }^{32}$.

Można odnieść wrażenie, że momentem mikrodoświadczenia śmierci jest chwila, w której pozujemy (lub precyzyjniej: czas reakcji fizyczno-chemicznej, wypalania czy też malowania — światłem w kliszy). Jednak po głębszej analizie za prawdziwe przeżycie metaforycznego zgonu uznać można użycie przez kogoś osobistej fotografii w kontekście niespójnym z naszą tożsamością. Podobne doświadczenie przeżywamy, gdy oglądamy swoje zdjęcia sprzed lat ze

co według nich ono wyraża. Podczas warsztatów, które odbyły się 16 marca 2018 roku, wyświetliłam wybrane, a uczniowie, którzy nie byli jego autorami, interpretowali tę konkretną fotografię. Następnie wyświetliłam opis autora. Intencja autorska a odbiór (notabene też fotografów) istotnie się różniły.

${ }^{31} \mathrm{~W}$ tym miejscu warto podjąć z uczniami dyskusję na temat selfie z Auschwitz, selfie na cmentarzu, selfie z monstrancją itp. Tego typu śladów nieprzemyślanych nadużyć mody na selfie można znaleźć w Internecie naprawdę sporo.

${ }^{32}$ Ibidem, s. 29-30. 
świadomością, że czas zmienił nas zarówno fizycznie, jak i psychicznie. Dobrze uświadomić sobie własną zmianę. Taka nostalgia pozwala w różnym stopniu doświadczyć „śmierci” i oswaja z myślą o naszej śmiertelności. Trzeba postawić pytanie: czy taką refleksję potrafi wzbudzić profil na portalu społecznościowym? Czy może tylko papierowa fotografia?

\section{Selfie w dydaktyce}

Fotografia, niezależnie czy dawna, czy współczesna, jawi się jako medium interpretacyjnie ograniczone. Być może dlatego zdjęcia na języku polskim wykorzystywane są najczęściej do obrazowania omawianych tekstów czy problemów, ale rzadko bywają przedmiotem interpretacji. By przezwyciężyć te metodologiczne trudności w odbiorze zdjęć, warto przejąć sposób, w jaki „czyta” fotografię Barthes. Proponuje on zgłębianie fotografii ,jedynie »uczuciowo« nie jako zagadnienie (temat), ale jako ranę" "33. Jedna z tez, które stawia, brzmi: „fotografia jest czystą przyległością i przypadkowością"34. I tym właśnie różni się od tekstu literackiego, że ukazuje wszystkie realia od razu ,inaczej niż tekst, który przez nagłą akcję jednego słowa może przesunąć zdanie od opisu do refleksji” ${ }^{35}$. Zdjęcie właściwie może stanowić tylko nośnik wiedzy etnologicznej, całą resztę muszą wykonać nasze wyobraźnia i myślenie, którego jakość zależy od intensywności zanurzenia w Kulturę. Metoda Barthes’a polega głównie na wpatrywaniu się w obraz, zamykaniu oczu, zobaczeniu fotografii w wyobraźni i ponownym oglądaniu zdjęcia. To, co dodane, pochodzi z wyobraźni i staje się zalążkiem interpretacji, dlatego warto od czasu do czasu pobudzić uczniów do kreatywnego myślenia poprzez kontakt z profesjonalną fotografią (np. wykorzystać zdjęcia nagrodzone w konkursie World Press Photo), nawet jeśli interpretacja ograniczyłaby się tylko do zadawania pytań.

Wprowadzanie zagadnienia selfie na lekcje języka polskiego przyniosło zaskakujące rezultaty. Z jednej strony wykorzystanie modnego zachowania pomogło stworzyć sytuację motywacyjną do zmierzenia się z dość trudnym tekstem eseistycznym. Z drugiej strony popularność i powszechność selfie sprawiła, że każdy uczeń był w stanie wziąć udział w dyskusji i wypowiedzieć się na jej temat. Ponadto wnioski, które pojawiły się w podsumowaniu lekcji, potwierdzają wnikliwe przemyślenie przez uczniów problemu umiejscowienia i funkcjonowania selfie w kulturze. Przykładowo, młodzież dostrzegła potrzebę pielęgnacji

\footnotetext{
33 Ibidem, s. 42.

34 Ibidem, s. 54.

35 Ibidem.
} 
starych fotografii, co paradoksalnie, w opozycji do wcześniej analizowanego problemu trwałości danych w Internecie, można zrobić poprzez zeskanowanie ich i przechowywanie na dyskach internetowych. I odwrotnie, uczniowie zauważyli, że warto wywoływać i gromadzić fotografie cyfrowe w albumach, by stwarzać okazję do rodzinnych spotkań, których częścią byłoby wspominanie i dzielenie się opowieściami z przeszłości. Niektórzy uczniowie postanowili nawet ograniczyć robienie sobie nic nieznaczących selfie na rzecz fotografowania innych ludzi czy wartościowych miejsc i wydarzeń. Jednym z pomysłów uczniowskich była gazetka stworzona z selfie $\mathrm{z}$ biblioteczką. Każdy miał za zadanie zrobić sobie zdjęcie ze swoimi ulubionymi książkami.

Zjawisko selfie ewoluuje i być może kwestie, które omawiam, są już zdezaktualizowane. Dziś zdjęcie zrobione samemu sobie przybiera formę krótkich filmów zamiast zdjęć profilowych, zdjęć z naklejkami i ramkami czy filmików kręconych tak, by być w ich centrum. Kultura medialna bardzo szybko się zmienia i choć trudno za nią nadążyć, warto poddawać ją refleksji.

\section{Bibliografia}

Barthes R.: Światto obrazu. Eseje o fotografii. Tłum. J. Trznadel. Warszawa 2008.

Berger J.: O patrzeniu. Tłum. S. Sikora. Warszawa 1999.

Brauchitsch B.: Mała historia fotografii. Tłum. J. Koźbiał, B. Tarnas. Warszawa 2004.

Dehnel J.: Fotoplastikon. Warszawa 2009.

Lubas-Bartoszyńska R.: Nowsze problemy teoretyczne pisania o sobie. Przyklady wypowiedzi autobiograficznych pisarzy ostatnich dziesięcioleci. „Przestrzenie Teorii” 2006, nr 6.

Nowicki W.: Dno oka. Eseje o fotografii. Wołowiec 2010.

Sontag S.: O fotografii. Tłum. S. Magala. Warszawa 1986.

\section{Źródła internetowe}

Scholz A.: Selfie ergo sum?. Tłum. P. Kasprzyk. http://www.cafebabel.pl/lifestyle/artykul/selfie-ergo-sum.html. 